\begin{tabular}{lc|}
\hline Bentham open & Open Biological Sciences Journal \\
CrossMark & Content list available at: www.benthamopen.com/BIOLSCI \\
DOI: $10.2174 / 2352633501703010009$ & Opd \\
\hline
\end{tabular}

RESEARCH ARTICLE

\title{
Phenotypic Correlation and Path Analysis in Sunflower Genotypes and Pollination Influence on Estimates
}

\author{
Emerson Dechechi Chambó ${ }^{1}$, Newton Tavares Escocard de Oliveira ${ }^{2}$, Regina Conceição Garcia ${ }^{2}$, \\ Maria Claudia Colla Ruvolo-Takasusuki ${ }^{3}$ and Vagner de Alencar Arnaut de Toledo ${ }^{4, *}$ \\ ${ }^{\prime}$ Grupo de Pesquisa Insecta, Universidade Federal do Recôncavo da Bahia, Cruz das Almas, Bahia, Brazil \\ ${ }^{2}$ Centro de Ciências Agrárias, Universidade Estadual do Oeste do Paraná, Marechal Cândido Rondon, Paraná, Brazil \\ ${ }^{3}$ Departamento de Biotecnologia, Genética e Biologia Celular, Universidade Estadual de Maringá, Maringá, Paraná, \\ Brazil \\ ${ }^{4}$ Departamento de Zootecnia, Universidade Estadual de Maringá, Maringá, Paraná, Brazil
}

Received: March 17, 2016

Revised: November 18, 2016

Accepted: November 21, 2016

\begin{abstract}
Eight sunflower genotypes were analyzed to estimate correlation values for nine agronomic traits. Path analysis was used to partition the correlation values into direct and indirect effects on seed yield in two pollination tests (open and restricted pollination). In both tests, there were significant $(p<0.05)$ positive correlation values between seed yield and head diameter, head mass, number and mass of achenes per head and first and last count of germination. There was no correlation $(p \geq 0.05)$ between seed yield and 1000 seed weight in both pollination tests. Oil content was not correlated $(p \geq 0.05)$ with seed yield in the open pollination, but it was positively correlated $(p<0.05)$ in restricted plants. The path analysis, in both pollination tests, indicated that head mass had the highest direct effect on seed yield. It can be concluded that the variables head mass and number of seeds per inflorescence (for pollination open) should get due attention in sunflower breeding programs, indirectly contributing to seed yield. In addition, for both pollination tests, the number of seeds per inflorescence has high significant positive correlation to the oil content and may contribute to its increase.
\end{abstract}

Keywords: Apis mellifera, Genetic breeding, Helianthus annuus, Pollinators, Seed yield, Selection.

\section{INTRODUCTION}

Sunflower (Helianthus annuus L.) is an important oilseed crop in world. The forecast for grain production in 2016/2017 is 43.8 million metric tons in 24.8 million hectares of acreage, with Ukraine, Russia, European Union, Argentina and Turkey being the world's largest producers [1]. For the 2015/2016 growing season, the Brazilian production of sunflower seeds is estimated at 64.2 thousand tons in 51.4 thousand hectares of acreage and average yield of $1,249 \mathrm{~kg} \mathrm{ha}^{-1}$ [2], i.e., $40.8 \%$ lower than that of the world average of $1.76 \mathrm{~kg}^{-h a^{-1}}$ [1].

As it is an allogamous plant, it needs cross-pollination, the presence of pollinating insects is essential for the production of sunflower seeds. In sunflower crop, a $43 \%$ increase in grain yield can be achieved with cross-pollination by introducing colonies of insect pollinators, mainly by Africanized honeybees [3]. Nevertheless, in Brazil, this is an uncommon practice, which limits increased production [4].

Traits related to seed yield components in sunflower have polygenic inheritances that are controlled by several pairs of genes located at different loci on the chromosomes. The characteristics of polygenic inheritance are determined by a combination of genetic (additive and non-additive) and environmental effects. The phenotypic correlations between

\footnotetext{
* Address correspondence to this author at the Universidade Estadual de Maringá, 5790 Colombo Avenue, zipcode 87020-900, Brazil; Tel: (+55) 4430118939; E-mail: vagner_abelha@yahoo.co.uk
} 
parameters measure the strength of the relationship of phenotypic values due to genetic and environmental factors [5]. The determination of the agronomic traits in sunflower is of utmost importance in breeding programs because it can help the breeder in the selection, since a certain parameter can change the behavior of another [6 - 8].

In breeding for increasing yield, it is important to find morphological and physiological characteristics that are easily measured and at the same time demonstrate a causal relationship with seed yield and therefore can be used as selection criteria [9]. The breakdown of the estimates of the phenotypic correlations into direct and indirect effects, by path analysis of agronomic traits, gives the breeder the possibility of indirect selection for grain yield [10].

In several regions of Brazil, breeding programs in sunflower to evaluate and select hybrids and varieties are performed through of the National Sunflower Trials, coordinated by Brazilian Agricultural Research Corporation Soybean (Embrapa Soja). The tests on the network for the selection of sunflower genotypes are held in different environments, favorable and unfavorable, to choose those genotypes with specific adaptation to each type of environment $[11,12]$.

Breeding programs that include the effect of pollination under plant genotypes, like abundance and/ or scarcity of pollinators that are responsible for higher yield in sunflower, for selecting the best genetic materials are scarce. The motivation of this study was due to lack of studies reporting the effect of pollination on the estimates of the correlation coefficients of productive components in sunflower. The aim was to determine the magnitude of these correlation coefficients, after their partitioning into direct and indirect effects on grain yield. The hypothesis of our study is that the pollination process can influence the estimates of associations between productive component traits in sunflower, which would entail different strategies in each production system, optimizing gains in breeding programs.

The present study estimated direct and indirect effects of correlations by path analysis of some seed yield components of sunflower genotypes under two pollination tests.

\section{MATERIAL AND METHODS}

The experiments were conducted in Marechal Cândido Rondon, state of Paraná, Brazil (24³3'40" S; 5404'00" W; $400 \mathrm{~m}$ a.s.1.), in the growing season of 2008/2009. The experimental area was $48 \mathrm{~m}$ in length, $26.6 \mathrm{~m}$ in width and 1,276 $\mathrm{m}^{2}$ of effective planted area. Eight commercial self-fertile sunflower cultivars were used in the study and each cultivar had a single capitulum per plant. The sowing of sunflower varieties Embrapa 122 (Brazilian Agricultural Research Corporation - EMBRAPA) and Catissol 01 and Multissol (Cordination of Integral Technical Assistance - Cati SP) and hybrids M734 and MG2 (Dow Agrosciences), Aguará and Charrua (Atlantica Seed LTDA) and Helio 360 (Helianthus annuus L. LTDA) was performed in 32 plots of $33.6 \mathrm{~m}^{2}$ each. Sowing occurred in eight rows spaced $0.70 \mathrm{~m}$ apart, with $0.30 \mathrm{~m}$ spacing between plants in the row. The sowing depth was $0.03 \mathrm{~m}$. After 20 days of emergence the plots were thinned to one plant per hole to adjust the number of plants per plot. All other recommended cultural practices were adopted for healthy crop growth during whole season.

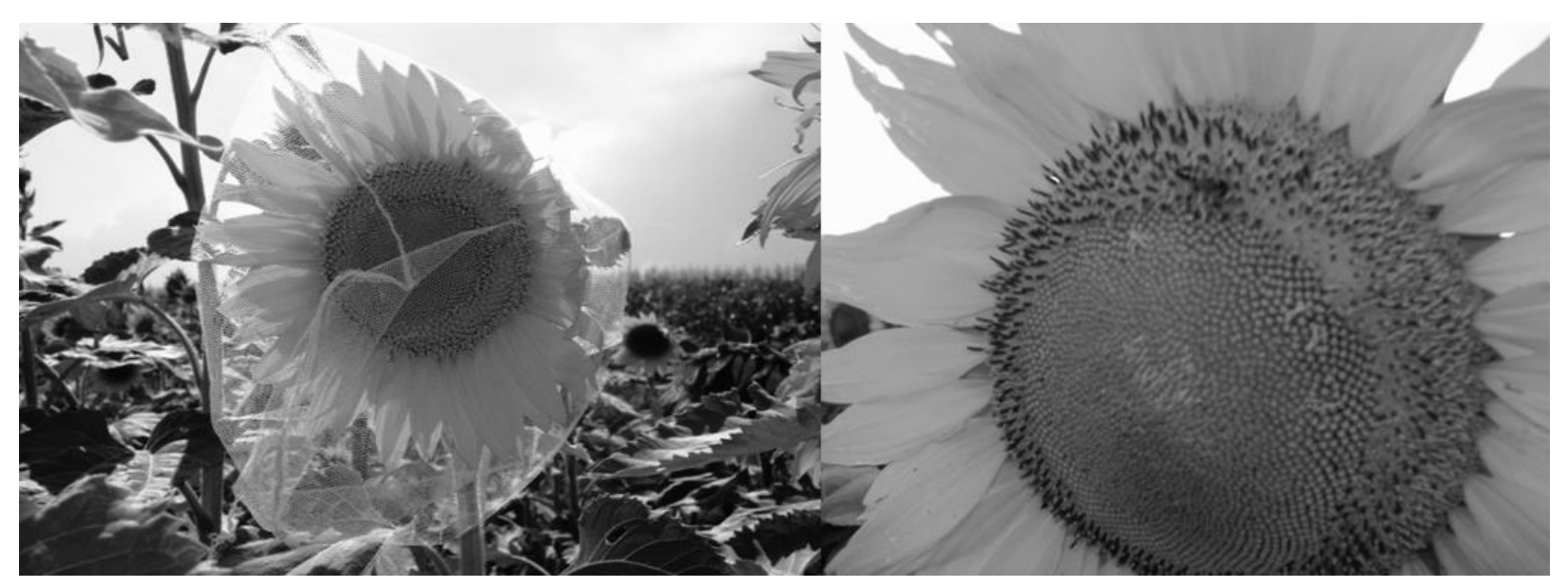

(A)

(B)

Fig. (1). Inflorescences (A) protected with tule and (B) without isolation. 
The experimental design was a randomized complete block in a split plot arrangement, with 16 treatments, four replications and 20 plants per plot and ten plants per subplot. Treatments were a combination of eight sunflower genotypes (Multissol, M734, Catissol 01, Charrua, MG2, Aguará, Helio 360 and Embrapa 122), randomized in the plots and two pollination tests (open and restricted pollination), assigned to the subplots. Before the flowering period, two Langstroth hives with Africanized Apis mellifera were introduced in the experimental area. Twenty inflorescences of each genotype were chosen at random in the useful area of each plot. Ten inflorescences were protected with tulle bags and the other ten were marked, but without isolation. Isolated inflorescences were monitored daily throughout the flowering period to ensure full restriction of flowers to pollinating insects (Fig. 1).

After maturation, which occurred 90 days after thinning plants, the capitulum were collected and dried in the shade for 30 days, weighed on electronic scales and their diameters measured with a digital caliper. Subsequently, all achenes present in capitulum were removed and processed.

The agronomic traits assessed were: a) main variable - seed yield $\left(\mathrm{kg} \mathrm{ha}^{-1}\right)$ and b) explanatory variables - head diameter $(\mathrm{cm})$, head mass $(\mathrm{g}), 1000$ seed weight $(\mathrm{g})$, number of achenes per head, mass of achenes per head (g), first count of germination $(\%)$, germination $(\%)$ and oil content $(\%)$.

The seed yield per treatment was estimated for a harvest standard adjusted to 45.000 plants ha ${ }^{-1}$. The moisture content of seeds was determined by the oven method at $105{ }^{\circ} \mathrm{C} \pm 30^{\circ} \mathrm{C}$ for $24 \mathrm{~h}$, with two replicates of each experimental unit [13]. The seed data was further transformed to $11 \%$ standard humidity according to Campos and Sader [14]. The average mass of 1000 seeds of each experimental unit (subplot) was determined from eight sub-samples of 100 seeds, according to Rules for Seed Analysis [13]. The number of achenes per inflorescence was calculated using the equation: total mass of achenes per inflorescence x 1000 seeds / mass 1000 seeds. The average achenes weight per inflorescence was determined by weighing in electronic scale of achenes present in each experimental unit (subplot). The germination test was conducted with four replicates of 25 seeds for each treatment. Seeds were sown in rolls of paper towels moistened with a water volume equal to 2.5 times the weight of the substrate maintained at a constant temperature of $25^{\circ} \mathrm{C}$. The count of normal seedlings occurred four (first count of germination) and 11 (germination) days after sowing, according to Rules for Seed Analysis [13]. The oil content in achenes was quantified by extraction hot method in ether with extractor type "Goldfish", with two replicates per treatment [15].

After the analysis of variance in a split plot arrangement, we considered, for path analysis, the significance of the pollination factor under seed yield, adopted as the main variable. From the matrices of phenotypic correlation between the parameters, estimated in each pollination test, we performed the breakdown of Pearson correlation coefficients into direct and indirect effects, through path analysis. The selection of the independent variables to explain seed yield was based on significance $(p<0.05)$ of the phenotypic correlation matrix coefficients and diagnosis of multicollinearity of $\mathrm{X}^{\prime} \mathrm{X}$ matrices. The criterion for multicollinearity analysis was the condition number of the $\mathrm{X}^{\prime} \mathrm{X}$ matrix [16]. We performed a Mantel test to determine the relationship between the matrices (open and restricted to pollinators). All statistical analyses were run in software GENES at 5\% significance [17].

\section{RESULTS}

The simple effect of pollination test was the factor adopted for the estimation of phenotypic correlations, as it allowed to obtain significant estimates $(p<0.05)$, possibly due to the larger sample size $(\mathrm{n}=32)$ compared to estimates of samples of traits obtained from the double interaction between sunflower genotypes and pollination tests $(n=4)$.

In both pollination tests, high significant positive estimates $(p<0.05)$ of the correlation coefficient were observed between seed yield and the variables head diameter, head mass, number of achenes per head, mass of achenes per head, first count of germination and germination. There was no correlation $(p \geq 0.05)$ between seed yield and 1000 seed weight in both pollination tests. For the oil content, there was no correlation $(p \geq 0.05)$ with seed yield in open pollination, but it was positively and significantly $(p<0.05)$ correlated in restricted plants (Table 1).

Table 1. Coefficients of phenotypic correlation of Pearson among nine agronomic traits examined in sunflower crop in two pollination tests.

\begin{tabular}{|c|c|c|c|c|c|c|c|c|c|}
\hline \multicolumn{10}{|c|}{ Open pollination $\left(r_{F}\right)$} \\
\hline Parameters $^{\mathrm{a}}$ & HD & HM & 1000SW & NAH & MAH & FCG & GER & OC & SY \\
\hline $\mathrm{HD}$ & 1.00 & & & & & & & & \\
\hline $\mathrm{HM}$ & $0.75^{*}$ & 1.00 & & & & & & & \\
\hline
\end{tabular}


(Table $\square$ ) contd.....

\begin{tabular}{|c|c|c|c|c|c|c|c|c|c|}
\hline \multicolumn{10}{|c|}{ Open pollination $\left(r_{F}\right)$} \\
\hline Parameters $^{\mathrm{a}}$ & HD & HM & $1000 S W$ & NAH & МАН & FCG & GER & OC & SY \\
\hline $1000 \mathrm{SW}$ & $0.30^{\text {ns }}$ & $0.42 *$ & 1.00 & & & & & & \\
\hline NAH & $0.33^{\text {ns }}$ & $0.51 *$ & $-0.37 *$ & 1.00 & & & & & \\
\hline MAH & $0.60 *$ & $0.84 *$ & $0.25^{\mathrm{ns}}$ & $0.76^{*}$ & 1.00 & & & & \\
\hline FCG & $0.24^{\text {ns }}$ & $0.48 *$ & $0.33^{\text {ns }}$ & $0.31^{\mathrm{ns}}$ & $0.55 *$ & 1.00 & & & \\
\hline GER & $0.25^{\mathrm{ns}}$ & $0.49 *$ & $0.33^{\text {ns }}$ & $0.30^{\text {ns }}$ & $0.55^{*}$ & $0.99 *$ & 1.00 & & \\
\hline $\mathrm{OC}$ & $-0.30^{\text {ns }}$ & $-0.16^{*}$ & $-0.66^{*}$ & $0.64 *$ & $0.14^{\mathrm{ns}}$ & $0.06^{\mathrm{ns}}$ & $0.03^{\mathrm{ns}}$ & 1.00 & \\
\hline SY & $0.59 *$ & $0.83^{*}$ & $0.24^{\mathrm{ns}}$ & $0.77 *$ & $0.99 *$ & $0.54 *$ & $0.55^{*}$ & $0.16^{\mathrm{ns}}$ & 1.00 \\
\hline \multicolumn{10}{|c|}{ Restricted pollination $\left(r_{\mathrm{F}}\right)$} \\
\hline Parameters & HD & HM & $1000 \mathrm{SW}$ & NAH & МАН & FCG & GER & OC & SY \\
\hline $\mathrm{HD}$ & 1.00 & & & & & & & & \\
\hline $\mathrm{HM}$ & $0.60^{*}$ & 1.00 & & & & & & & \\
\hline $1000 \mathrm{SW}$ & $0.46^{*}$ & $0.20^{\mathrm{ns}}$ & 1.00 & & & & & & \\
\hline $\mathrm{NAH}$ & $0.39 *$ & $0.86^{*}$ & $-0.18^{\text {ns }}$ & 1.00 & & & & & \\
\hline MAH & $0.52 *$ & $0.95 *$ & $0.10^{\mathrm{ns}}$ & $0.95^{*}$ & 1.00 & & & & \\
\hline FCG & $0.13^{\mathrm{ns}}$ & $0.46^{*}$ & $-0.19^{\text {ns }}$ & $0.56^{*}$ & $0.56^{*}$ & 1.00 & & & \\
\hline GER & $0.08^{\text {ns }}$ & $0.46^{*}$ & $-0.22^{\text {ns }}$ & $0.58^{*}$ & $0.57 *$ & $0.99 *$ & 1.00 & & \\
\hline $\mathrm{OC}$ & $0.08^{\text {ns }}$ & $0.49 *$ & $-0.41 *$ & $0.65^{*}$ & $0.57 *$ & $0.69 *$ & $0.71^{*}$ & 100 & \\
\hline SY & $0.51 *$ & $0.94 *$ & $0.09^{\mathrm{ns}}$ & $0.95 *$ & $0.99 *$ & $0.56 *$ & $0.58 *$ & $0.58 *$ & 1.00 \\
\hline
\end{tabular}

${ }^{\mathrm{a}} \mathrm{HD}$ - head diameter; HM - head mass; 1000SW - 1000 seed weight; NAH- number of achenes per head; MAH - mass of achenes per head; FCG first count of germination; GER - germination; OC - oil content; SY - seed yield. *Significant at $5 \%$ probability $(p>/ \mathrm{r} / \mathrm{H}$ : $0 / \mathrm{n}=32)$. ns $-\mathrm{non}-$ significant.

The correlation matrix between pollination tests (open and restricted pollination) was weak $(r=0.3)$, but significant by Mantel's test $(p=0.01)$. The $\mathrm{X}^{\prime} \mathrm{X}$ phenotypic correlation matrix of the explanatory variables indicated high multicollinearity (condition number $>1000$ ) when all parameters were included in the analysis. After deleting the explanatory variables with the highest condition numbers from the $\mathrm{X}^{\prime} \mathrm{X}$ phenotypic correlation matrix in each pollination test, there was a weak multicollinearity, revealing the absence of serious problems for carrying out the path analysis [16].

The proportion of explained variation $\left(\mathrm{R}^{2}\right)$ in seed yield in the open and restricted pollination was 0.87 and 0.92 , respectively. For open pollination test, the path analysis showed that the parameters head mass and number of achenes per head had the highest direct effects $(r=0.52$ and $r=0.46$, respectively) compared to the main variable, seed yield. Head diameter and germination presented lower direct effects $(\mathrm{r}=0.009$ and 0.15 , respectively) on seed yield, although they have had high positive correlations with this variable. For restricted pollination test, head mass presented the highest direct effect $(\mathrm{r}=0.87)$ with respect to the main variable. Head diameter and oil content presented negative $(\mathrm{r}=$ $-0.03)$ and positive $(r=0.05)$ direct effects, respectively, on seed yield, although estimates of these correlations were high and positive with this variable (Table 2).

Table 2. Direct (DE) and indirect (IE) effects estimates of agronomic traits on seed yield in sunflower crop under two pollination tests (open and restricted).

\begin{tabular}{|c|c|c|c|}
\hline \multirow[t]{2}{*}{ Parameters $^{a}$} & \multicolumn{3}{|c|}{ Breakdown of $r_{x y}$} \\
\hline & Open & Parameters $^{\mathrm{a}}$ & Restricted \\
\hline HD & & HD & \\
\hline DE via SY & 0.009 & DE via SY & -0.03 \\
\hline IE via $\mathrm{HM}$ & 0.39 & IE via $\mathrm{HM}$ & 0.53 \\
\hline IE via $\mathrm{NAH}$ & 0.15 & IE via GER & 0.01 \\
\hline IE via GER & 0.04 & IE via $\mathrm{OC}$ & 0.004 \\
\hline Total $r_{x y}$ & 0.59 & Total $\mathrm{r}_{\mathrm{xy}}$ & 0.51 \\
\hline HM & & HM & \\
\hline DE via SY & 0.52 & IE SY & 0.87 \\
\hline IE via HD & 0.007 & IE via $\mathrm{HD}$ & -0.02 \\
\hline IE via $\mathrm{NAH}$ & 0.24 & IE via GER & 0.07 \\
\hline IE via GER & 0.07 & IE via $\mathrm{OC}$ & 0.03 \\
\hline
\end{tabular}


(Table $\square$ ) contd.....

\begin{tabular}{|c|c|c|c|}
\hline \multirow[t]{2}{*}{ Parameters $^{a}$} & \multicolumn{3}{|c|}{ Breakdown of $r_{x y}$} \\
\hline & Open & Parameters $^{\mathrm{a}}$ & Restricted \\
\hline Total $r_{\mathrm{xy}}$ & 0.83 & Total $r_{x y}$ & 0.94 \\
\hline $\mathrm{NAH}$ & & GER & \\
\hline $\mathrm{DE}$ via $\mathrm{SY}$ & 0.46 & DE via $\mathrm{SY}$ & 0.15 \\
\hline IE via HD & 0.003 & IE via HD & -0.002 \\
\hline IE via HM & 0.26 & IE via HM & 0.40 \\
\hline IE via GER & 0.05 & IE via OC & 0.36 \\
\hline Total $r_{x y}$ & 0.77 & Total $r_{x y}$ & 0.58 \\
\hline GER & & $\mathrm{OC}$ & \\
\hline $\mathrm{DE}$ via $\mathrm{SY}$ & 0.15 & DE via $\mathrm{SY}$ & 0.05 \\
\hline IE via HD & 0.002 & IE via HD & -0.002 \\
\hline IE via HM & 0.25 & IE via HM & 0.42 \\
\hline IE via $\mathrm{NAH}$ & 0.14 & IE via GER & 0.10 \\
\hline Total $r_{x y}$ & 0.55 & Total $r_{x y}$ & 0.58 \\
\hline Coefficient of determination $\left(\mathrm{R}^{2}\right)$ & 0.87 & Coefficient of determination $\left(\mathrm{R}^{2}\right)$ & 0.92 \\
\hline Effect of the residual variable & 0.36 & Effect of the residual variable & 0.28 \\
\hline
\end{tabular}

${ }^{\mathrm{a}} \mathrm{HD}$ - head diameter; HM - head mass; NAH - number of achenes per head; GER - germination; OC - oil content; SY - seed yield.

\section{DISCUSSION}

There were differences in the magnitude of the phenotypic correlation coefficients between pollination tests (open and restricted pollination) (Table 1) and low correlation, indicated by Mantel's test, between the two correlation matrices. The implications of the tested environmental effects (open and restricted pollination) on the phenotypic correlation coefficients are of fundamental importance for conducting of a breeding program and decision-making. The existing phenotypic variability in the correlation coefficients in each pollination test indicates that genetic improvement strategies should be adopted in each production system, that is, in abundance and scarcity of pollinators.

Studies dealing with differences in magnitudes between production systems are scarce in the literature of sunflower. We did not find relationships between seed yield and 1000 seed weight and we find significant negative correlations between oil content and 1000 seed weight in both pollination tests. In case of early harvesting or early desiccation, the 1000 seed weight may have negative impact on seed yield and oil content [18]. A significant positive correlation was found between seed yield and head diameter (0.63) and between seed yield and 1000 seed weight (0.55), but not between seed yield and oil content [10]. Significant positive correlation were observed between seed yield per plant and the parameters of plant height, head diameter, 1000 seed weight and oil yield [19]. Significant negative correlation values between ether extract content and the parameters of 1000 seed weight and seed yield $(r=-0.85$ and $r=-0.71$, respectively) were reported by [20].

Radić et al. [21] evaluated ten female parental lines of sunflower and registered significant positive correlations between seed yield and the parameters of 1000 seed weight $(r=0.40)$ and oil content $(0.27)$, but significant negative correlation between seed yield and germination $(\mathrm{r}=-0.31)$. In sunflower, seed yield per plant was positively and significantly correlated with head diameter $(0.86)$, plant height $(0.78)$, number of achenes per head $(0.67)$ and number of foliar characteristics (0.67), when genotypes were subjected to good irrigation [22]. However, in the absence of irrigation, the same authors reported that the seed yield per plant was positively and significantly correlated with the parameters of head mass (0.46), head diameter (0.84), number of achenes per head (0.85) and chlorophyll content (0.48).

The high, positive, significant estimates of phenotypic correlations obtained in this study indicate the possibility of promoting increased seed yield (Table 1). Nevertheless, most of the explanatory variables are correlated with one another, which present the complexity of the relationship between traits related to yield. Therefore, obtaining sunflower genotypes with higher seed yield should be focused when breaking down the correlations into direct and indirect effects, to assess the degree of importance of each of the explanatory variables with the main variable [23].

The magnitudes of the direct effects of the parameters examined for seed yield, in both pollination tests, were lower than the magnitudes of the estimates of their respective correlations with seed yield (Table 2). These results confirm those obtained by Amorim et al. [10] in sunflower.

The phenotypic correlation coefficients of some productive characters were partitioned in direct and indirect effects 
on seed yield, in each pollination test, to investigate the selection criteria in sunflower breeding. It can be seen that there were differences between tests regarding the magnitude of the coefficient estimates (Table 2). For open pollination test, the highest direct effect (0.52) was exhibited by head mass, followed by number of achenes per head (0.46). For restricted pollination test, the highest direct effect (0.87) was exhibited by head mass. Earlier, Radić et al. [21], conducted a path analysis in sunflower and found that the 1000 seed weight was the parameter with the highest positive direct effect (0.339) and germination presented the greatest negative direct effect on seed yield. Likewise, after applying path analysis on sunflower genotypes grown under water stress or good irrigation, Darvishzadeh et al. [22], reported that in both conditions the head diameter and the number of achenes per head were the parameters with major positive direct effects on seed yield.

In sunflower, number of achenes per head is conditioned by the number of tubular flowers formed, attractiveness to pollinators and the factors in the external environment during flowering and pollination. To achieve high seed yield per unit area it is necessary to increase the number of seeds per inflorescence up to more than 2.000 [24]. Thus, our results suggest that the breeding for increasing the number of achenes per head and the head mass may significantly contribute to increase seed yield, especially in farming systems with the presence of pollinating insects, in particular Africanized A. mellifera honeybees. Furthermore, in farming systems with shortage of pollinators, among the seed yield components assessed, only head mass was an important component of seed yield.

The sunflower is a crop predominantly cross-pollinated. Numerous studies have reported the increases in grain yield from the cross- pollination by pollinating insects, especially A. mellifera $[3,25,26]$. Chammer et al. [27] reported the importance of pollinators for the sunflower crop and suggest that some grain yield components may be sensitive to the quantity and quality deposited by pollinating pollen stigma in the plant.

Therefore, it is possible to infer that there are other parameters influencing both the magnitude and the direction of the correlations between the explanatory variables and the main variable, seed yield in sunflower. Besides, not there was similarity between the estimates of the phenotypic correlations and direct and indirect effects of the explanatory variables on seed yield in both pollination tests, suggesting that the production system (open and restricted pollination) has influence on estimates of phenotypic correlations between yield components and seed yield.

Also, based on our analysis, it is suggested that more research is required to investigate the relationship between certain parameters associated with the physiological quality of seeds, as well as those associated with seed yield components, to obtain high quality sunflower seeds.

\section{CONCLUSION}

It can be concluded that the characters head mass and number of seeds per inflorescence (for opened pollination) should get due attention in sunflower breeding programs, indirectly contributing seed yield. In addition, for both pollination tests, the number of seeds per inflorescence has high significant positive estimate to the oil content and may contribute to its increase.

\section{CONFLICT OF INTREST}

The authors confirm that this article content has no conflict of interest.

\section{ACKNOWLEDGEMENTS}

The authors acknowledge Coordenação de Aperfeiçoamento de Pessoal de Nível Superior (CAPES) for financial support.

\section{REFERENCES}

[1] USDA - United States Department of Agriculture. Oilseeds: world markets and trade. Washington: USDA 2016 Available at: http://apps.fas.usda.gov/psdonline/circulars/oilseeds.pdf-. Accessed on: 20 September 2016.

[2] CONAB - National Food Supply Company. Monitoring of the Brazilian harvest Brasília: CONAB 2016 2016. Available at: http://www.conab.gov.br. [Accessed date: 20 September 2016]

[3] Chambó ED, Garcia RC, Oliveira NT, Duarte-Júnior JB. Honey bee visitation to sunflower: effects on pollination and plant genotype. Sci Agric 2011; 68(6): 647-51.

[http://dx.doi.org/10.1590/S0103-90162011000600007]

[4] Toledo VAA, Chambó ED, Halak AL, et al. Biologia floral e polinização em girassol (Helianthus annuus L.) por abelhas africanizadas Sci Ag Paran 2011; 10(1): 05-17. 
[5] Falconer DS, Mackay TF. Introduction to quantitative genetics. Edinburgh: Addison Wesley Longman 1996.

[6] Shankar VG, Ganesh M, Ranganatha AR, Bhave MH. A study on correlation and path analysis of seed yield and yield components in sunflower (Helianthus annuus L.). Agric Sci Dig 2006; 26(2): 87-90.

[7] Farratullah FE, Khalil IH. Path analysis of the coefficients of sunflower (Helianthus annuus L.) hybrids. Int J Agric Biol 2006; 8(5): 621-5.

[8] Arshad M, Ilyas MK, Khan MA. Genetic divergence and path coefficient analysis for seed yield traits in sunflower (Helianthus annuus L.) hybrids. Pak J Bot 2007; 39(6): 2009-15.

[9] Hladni N, Škorić D, Kraljević-Balalić M, Sakač Z, Miklič V. Heterosis for agronomically important traits in sunflower (Helianthus annuus L.). Helia 2007; 30(47): 191-8. [http://dx.doi.org/10.2298/HEL0747191H]

[10] Amorim EP, Ramos NP, Ungaro MR, Kiihl TA. Correlações e análise de trilha em girassol. Brag 2008; 67(2): 307-16. [http://dx.doi.org/10.1590/S0006-87052008000200006]

[11] de la Vega AJ, Chapman SC. Defining sunflower selection strategies for a highly heterogeneous target population of environments. Crop Sci 2006; 46(1): 136-44.

[http://dx.doi.org/10.2135/cropsci2005.0170]

[12] Porto WS, Carvalho CG, Pinto RJ. Adaptabilidade e estabilidade como critérios para seleção de genótipos de girassol. Pesquisa Agropecu Bras 2007; 42(4): 491-9.

[http://dx.doi.org/10.1590/S0100-204X2007000400006]

[13] Brazil. Department of Agriculture. Seed rules for production, trading and use Brasília: MAPA/SNPC, Brasília 2009.

[14] Campos MS, Sader R. Effect of potassic on the production and seed quality of sunflower. Rev Bras Sem 1987; 9: 19-27. [http://dx.doi.org/10.17801/0101-3122/rbs.v9n3p19-27]

[15] Silva DJ, Queiroz AC. Análise de alimentos: métodos químicos e biológico. Viçosa: UFV 2002.

[16] Montgomery DC, Peck EA, Vining GG. Introduction to linear regression analysis. New York: Wiley 2001.

[17] Cruz CD. A software package for analysis in experimental statistics and quantitative genetics. Acta Sci Agron 2013; 35(3): 271-6. [http://dx.doi.org/10.4025/actasciagron.v35i3.21251]

[18] Miklic V, Mrda J, Modi R, et al. Effect of location and harvesting date on yield and 1,000-seed weight of different sunflower genotypes. Rom Agric Res 2012; 29: 219-25.

[19] Teklewold A, Jayaramaiah H, Jagadeesh BN. Correlations and path analysis of physio-morphological characters of sunflower (Helianthus annuus L.) as related to breeding method. Helia 2000; 23(32): 105-14.

[20] Hladni N, Škorić D, Kraljević-Balalić M, Sakač Z, Jovanović D. Combining ability for oil content and its correlations with other yield components in sunflower (Helianthus annuus L.). Helia 2006; 29(44): 101-10. [http://dx.doi.org/10.2298/HEL0644101H]

[21] Radić V, Mrda J, Terzić S, et al. Correlations and path analyses of yield and other sunflower seed characters. Genet 2013; $45(2)$ : $459-66$. [http://dx.doi.org/10.2298/GENSR1302459R]

[22] Darvishzadeh R, Maleki H, Sarrafi A. Path analysis of the relationships between yield and some related traits in diallel population of sunflower (Helianthus annuus L.) under well-watered and water-stressed conditions. Aust J Crop Sci 2011; 5(6): 674-80.

[23] Oliveira EJ, Lima DS, Lucena RS, Motta TB, Dantas JL. Correlações genéticas e análise de trilha para número de frutos comerciais por planta em mamoeiro. Pesquisa Agropecu Bras 2010; 45(8): 855-62. [http://dx.doi.org/10.1590/S0100-204X2010000800011]

[24] Hladni N, Škorić D, Kraljević-Balalić M, Jocić S, Dušanić N. Line x tester analysis for yield components in sunflower and their correlations with seed yield (Helianthus annuus L.). Genet 2011; 43(2): 297-306.

[http://dx.doi.org/10.2298/GENSR1102297H]

[25] Nderitu J, Nyamasyo G, Kasina M, Oronje ML. Diversity of sunflower pollinators and their on seed yield in Makueni District, Eastern Kenya. Span J Agric Res 2008; 6(2): 271-8. [http://dx.doi.org/10.5424/sjar/2008062-318]

[26] Oz M, Karasu A, Cakmak I, Goksoy AT, Turan ZM. Effects of honey bee (Apis mellifera) pollination on seed set in hybrid sunflower (Helianthus annuus L.). Afr J Biotechnol 2009; 8(6): 1037-43.

[27] Chammer AM, Medan D, Mantese AI, Bartoloni NJ. Impact of pollination on sunflower yield: is pollen amount or pollen quality what matters? Field Crops Res 2015; 176: 61-70.

[http://dx.doi.org/10.1016/j.fcr.2015.02.001]

(C) Chambó et al.; Licensee Bentham Open

This is an open access article licensed under the terms of the Creative Commons Attribution-Non-Commercial 4.0 International Public License (CC BY-NC 4.0) (https://creativecommons.org/licenses/by-nc/4.0/legalcode), which permits unrestricted, non-commercial use, distribution and reproduction in any medium, provided the work is properly cited. 